\title{
https://doi.org/10.46813/2021-136-133 \\ VACUUM SYSTEM OF KLYSTRON REPAIR FACILITY FOR ELECTRON ACCELERATORS
}

\author{
R.M. Dronov, M.V. Ivakhnenko, V.O. Mats, Yu.O. Titarenko, V.Yu. Titov \\ National Science Center "Kharkov Institute of Physics and Technology", Kharkiv, Ukraine \\ E-mail: romandronov@kipt.kharkov.ua
}

KIU-12AM "AVRORA" klystron has been the main source of rf power for the accelerators for decades. Large accumulations of malfunctioning klystrons made it possible to recycle them using the donor parts, which are well preserved and still functional. Klystron repair process comprises of few stages and part of these stages requires maintaining the high vacuum inside the klystron and adjacent systems.

PACS: 84.40.Fe, 29.17.+w

\section{DESCRIPTION OF VACUUM SYSTEM}

The design goal for the vacuum system is the pressure inside the klystron tube to be less than $5 \cdot 10^{-7}$ Torr.

Previously existed vacuum system (Fig. 1) consisted of four sputter ion pumps (N1-250 1/s, N2-15 1/s, N6$15 \mathrm{l} / \mathrm{s}, \mathrm{N} 7-4 \mathrm{l} / \mathrm{s}$, ) and a roughing pump. Using such vacuum system, thirty-seven KIU-12AM "AVRORA" klystrons were previously repaired [1].

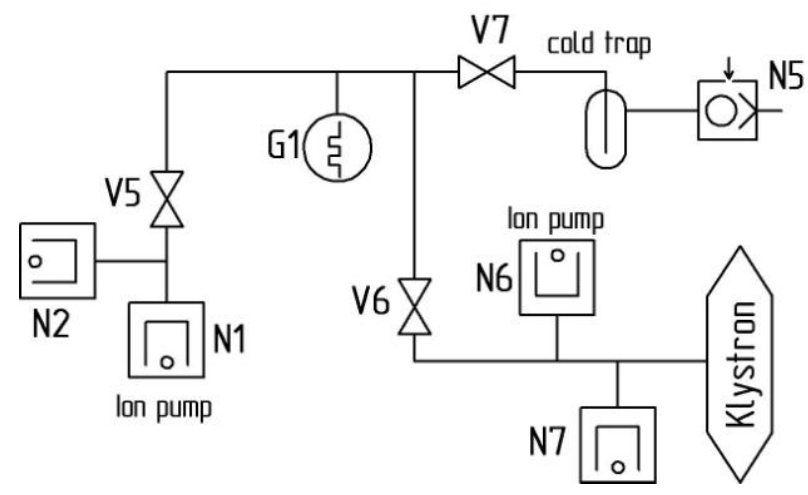

Fig. 1. Schematic diagram of vacuum system before modernization

During all previous restorations total time of baking and cathode activation lasted relatively long time (approx. $150 \mathrm{~h}$ ) which was not acceptable in terms of cost and operational schedule. In order to reduce the total duration we decided to improve the system. The main part of vacuum system improvement is adding of the turbo molecular pump Turbo-V 750 Twis Torr with pumping speed $700 \mathrm{l} / \mathrm{s}$. Turbo molecular pump is backed by Dry Scroll Pump TriScroll300 with pumping speed 210 1/s. Few additional valves and vacuum gauges were installed too. Vacuum system schematically presented in Fig. 2 and new appearance of it is shown in Fig. 3. Newly added elements of vacuum system are visible on the Fig. 2 above the horizontal dashed line.

Safe operation of newly added equipment required presence of controlling unit that performs all necessary commutation and safety interlocks. Such controlling unit has been designed and manufactured. Safety interlocks have been incorporated for isolation of turbo molecular pump in case of accidental depressurization of vacuum system or power failure. Electric diagram of controlling unit and overall appearance of it are shown in Figs. 4 and 5.

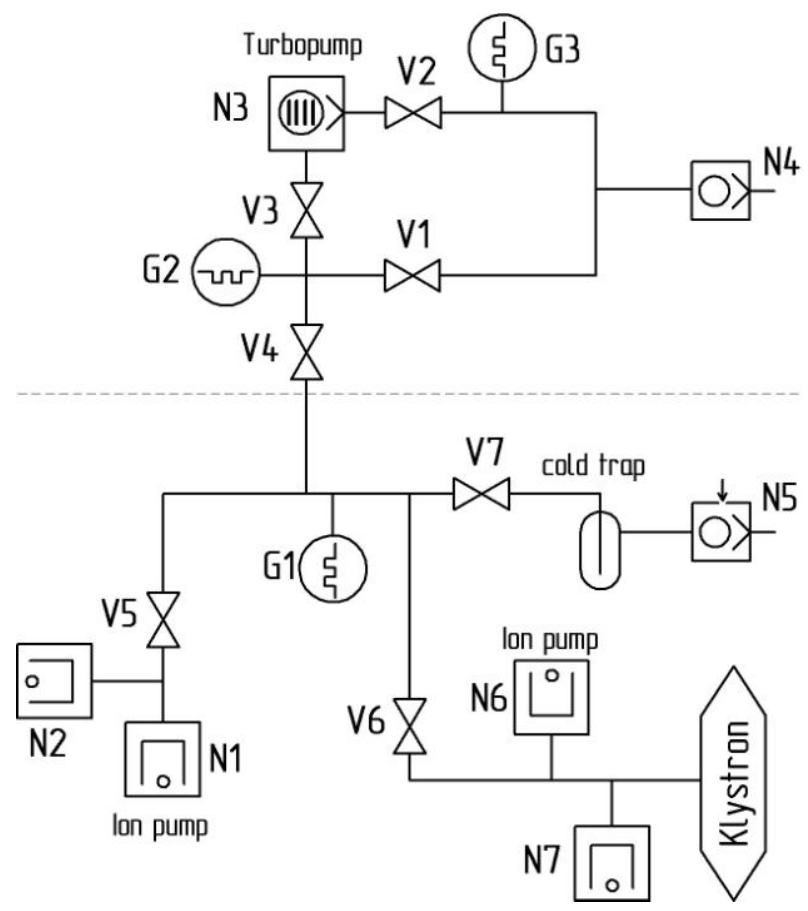

Fig. 2. Schematic diagram of vacuum system after modernization

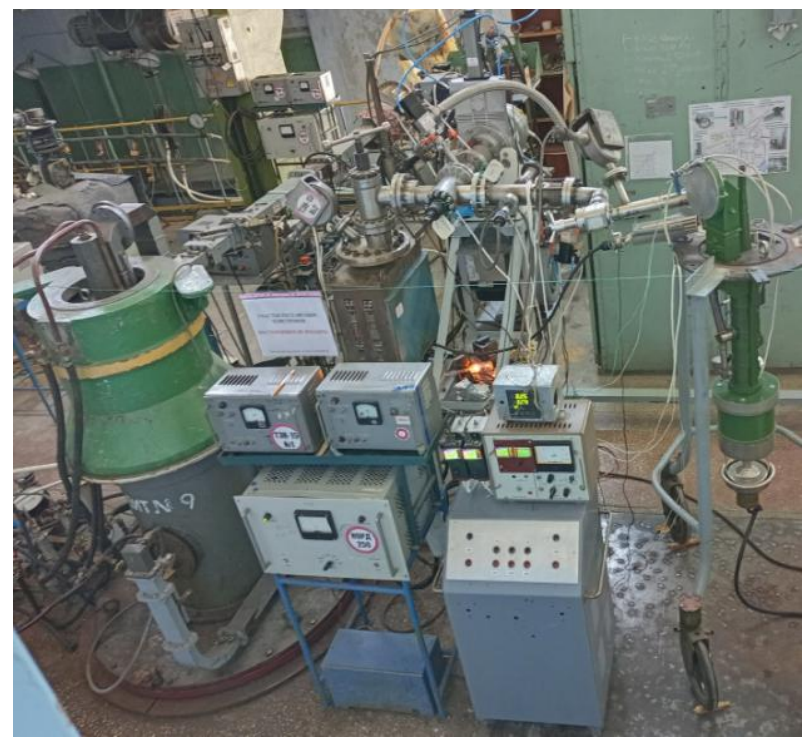

Fig. 3. Configuration of modernized vacuum system during klystron baking and cathode activation 


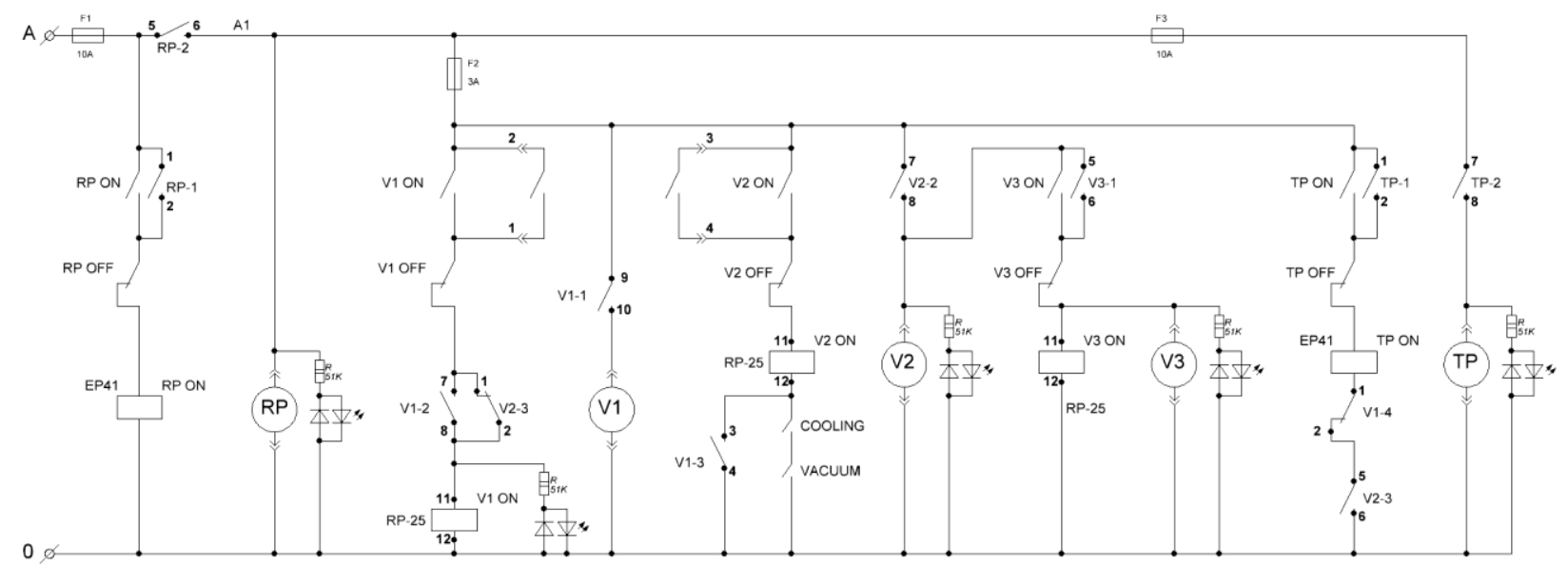

Fig. 4. Schematic diagram of controlling unit of vacuum system

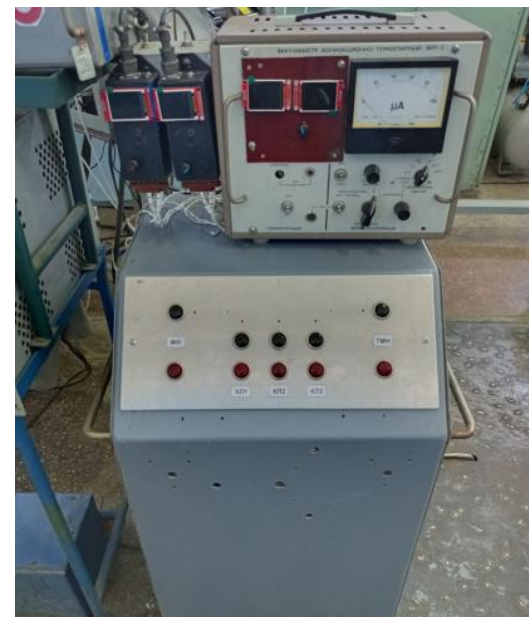

Fig. 5. Controlling unit of vacuum system

Within framework of this upgrade VIT-2 (ВИТ-2) vacuum gauge controller has been upgraded using STM32 microcontrollers and 18-Bit ADC. This made it possible to digitize the readings of both PMT-4 (ПМТ-4) thermocouple vacuum gauge and PMI-2 (ПМИ-2) ionization vacuum gauges. These vacuum gauges were incorporated in controlling unit of whole system.

Configuration of the system during $\mathrm{HV}$ and $\mathrm{RF}$ training of klystron is shown in Fig. 6.

\section{SUMMARY}

As a result of vacuum system modernization total duration of baking and cathode activation during klystron restoration decreased from 150 to 85 hours.

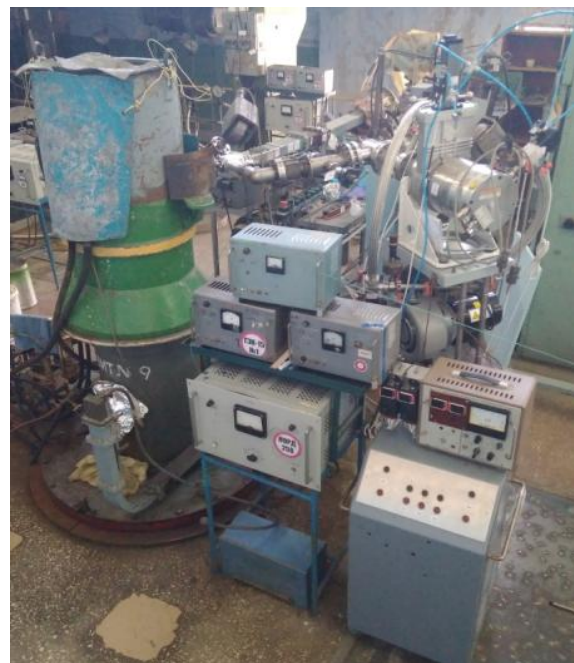

Fig. 6. Configuration of vacuum system during $H V$ and RF training of klystron

\section{ACKNOWLEDGEMENT}

We gratefully acknowledge the assistance of Volodymyr Tsymbal and Denis Shakhov in modernization of the system.

\section{REFERENCES}

1. V.N. Boriskin, R.N. Dronov, R.A. Efimov, Yu.D. Tur. Preparation and exploitation of powerful klystron amplifiers for Linac RF power supply // Problems of Atomic Science and Technology. Series "Nuclear Physics Investigations”. 2012, № 3, p. 70-75.

Article received 21.09.2021

\section{ВАКУУМНАЯ СИСТЕМА УСТАНОВКИ ПО РЕСТАВРАЦИИ КЛИСТРОНОВ ДЛЯ УСКОРИТЕЛЕЙ ЭЛЕКТРОНОВ Р.Н. Дронов, М.В. Ивахненко, В.А. Мац, Ю.А. Титаренко, В.Ю. Титов}

Клистрон КИУ-12АМ «АВРОРА» в течение многих десятилетий был основным источником радиочастотной мощности для ускорителей в ННЦ ХФТИ. Несмотря на то, что этот клистрон больше не производится, он все еще используется. Наличие большого количества неисправных клистронов дает возможность их реставрировать, подбирая донорские компоненты, которые до сих пор находятся в работоспособном состоянии. Процесс ремонта клистрона состоит из нескольких этапов, и часть из этих этапов требует поддержания высокого вакуума внутри клистрона и в смежных системах.

\section{ВАКУУМНА СИСТЕМА УСТАНОВКИ З РЕСТАВРАЦІЇ КЛІСТРОНІВ ДЛЯ ПРИСКОРЮВАЧІВ ЕЛЕКТРОНІВ}

\section{Р.М. Дронов, М.В. Івахненко, В.О. Мац, Ю.О. Тітаренко, В.Ю. Тітов}

Клістрон КІУ-12АМ «АВРОРА» протягом багатьох десятиліть був основним джерелом радіочастотної потужності для прискорювачів у ННЦ ХФТІ. Незважаючи на те, що цей клістрон більше не виготовляється, він все ще використовується. Наявність великої кількості несправних клістронів дає можливість їх реставрувати підбираючи донорські компоненти, які досі перебувають у робочому стані. Процес ремонту клістрона складається 3 декількох етапів, і частина 3 цих етапів вимагає підтримання високого вакууму всередині клістрона та в допоміжних системах. 